\title{
Meeting The Needs Of Nurses In Efforts By The Spiritual Self Improvement Of Efficacy Of Patients With Terminal Disease In The Hospital Ward
}

\author{
Heri Saputro*, Sri Astutik, Petrus Kondo, Cici Bagawanti \\ Nursing Departement, STRADA Indonesia Institute of Health Sciences, Indonesia \\ *intelsehat@gmail.com
}

\begin{abstract}
In patients with terminal disease appears fear, nervousness and anxiety about something that is uncertain. The feelings in people with terminal illness one of them due to low self efficacy, in which patients are not sure of his recovery. Spiritual fulfillment can help improve self-efficacy. The purpose of this study was to determine the influence of spiritual fulfillment by nurses in an effort to increase self efficacy in patients with terminal illness. This study research design Correlation Study with Cross Sectional approach. Technics sampling Simple random sampling with a sample of 21 respondents. The research instrument used questionnaire. Statistical data analysis Pearson correlation test. Most of the respondents 66.7\% (14 people) were spiritual needs. Nearly half of the respondents $57.1 \%$ (12 people) are not too sure will be able to live the rest of his life with better. Statistical test results obtained $p$-value was $p=0.006$, which means reject Ho conclusion there is no relationship spiritual fulfillment by nurses in an effort to increase self efficacy of patients with terminal illness. Nurses provide spiritual fulfillment is better, then the patient will have the confidence that he is more meaningful or useful to others and be able to get closer to God Almighty and be ready at any time to die comes so spiritual fulfillment good nurse will help improve self efficacy of patients.
\end{abstract}

Keywords: Patient terminal, Self-efficacy, Spiritual Needs 


\section{STRADA Jurnal Ilmiah Kesehatan}

DOI: $10.30994 /$ sjik.v9i1.284

ISSN: 2252-3847 (print); 2614-350X (online)

Vol.9 No.1. May 2020. Page.272-278

\section{INTRODUCTION}

Loss, death and grieving are events that are closely related to terminal illness. In patients with terminal illness there is fear, anxiety and anxiety about something that is uncertain. The emergence of these feelings in patients with terminal illness is one of them due to low selfefficacy, where patients are not sure of his recovery (Suseno, 2012).

Self efficacy determines the ability of people to deal with problems where humans can anticipate death from the terminal conditions they face. Someone's self efficacy depends on one's beliefs and emotional strength, which can affect individual coping mechanisms (Suseno, 2012).

Self efficacy is influenced by a person's knowledge which can influence the behavior of terminal patients and this affects the process of palliative healing, although terminal illness is only a delay in death, but at least it will alleviate the psychological suffering of the patient (Kozier, 2010).

Self efficacy is important to succeed in changing and maintaining every behavior that is important for health. The low self-efficacy in individuals, tends to cause stress which affects the health and immune system of the individual. (Maddux, 2012).

According to Ferrel (2012) there are several problems related to terminal illnesses, namely physical, psychological, social, spiritual decline, loss of hope and planning when death arrives, discrepancies, between needs and expectations with the treatment they get. Psychological and spiritual problems that arise next are the loss of hope of healing.

Spiritual needs are the basic needs needed by every human being. If someone is in a state of illness, then the relationship with his Lord is getting closer, remembering someone in a condition of illness becomes weak in everything, no one is able to raise him from healing, except the Creator. In health services, nurses as health workers must have a major role in meeting spiritual needs in an effort to increase patient self-efficacy or increase new high self-confidence. Nurses are required to be able to provide more fulfillment when the patient is critical or near death (Hidayat A.A, 2013).

Self efficacy related to physiological aspects of health; people who do not have self efficacy experience stress that affects their health and immune system. Self efficacy is also related to the potential of individuals to behave healthily; people who are not sure that they can perform a behavior that can support health will tend to be reluctant to try it. Nurses are expected to be able to improve the patient's self-efficacy, including nurses' roles as nursing care givers, patient advocates, educators, coordinators, collaborators, consultants, and researchers (Bandura, 1997, in Mustaqim 2011).

Nurses as health professionals who have the greatest opportunity to provide health services and spiritual needs so that patients are able to increase self-efficacy. The role of nurses in meeting spiritual needs includes nursing care providers, patient advocates, educators, coordinators, collaborators, consultants, and researchers. Nurses see clients as bio-psycho socio-cultural and spiritual beings who respond holistically and uniquely to changes in health or in a state of crisis. Nurses try to increase patient self-efficacy by providing motivation to always get closer to God Almighty, teaching how to worship in bed by facilitating the fulfillment of the client's spiritual needs, even though the nurse and client do not have the same spiritual or religious beliefs. (Hamid, 2000 in Sumiati, et al., 2011). 


\section{STRADA Jurnal Ilmiah Kesehatan}

DOI: $10.30994 /$ sjik.v9i1.284

ISSN: 2252-3847 (print); 2614-350X (online)

Starting from this fact researchers were interested in conducting research on meeting the spiritual needs of nurses in an effort to improve the self-efficacy of patients with terminal illness in the Inpatient Room at DKT Hospital in Kediri City.

\section{METHODS}

The research design used is correlation analytic with cross sectional approach. Correlation analytic method in this study is used to measure the relationship of spiritual needs fulfillment by nurses in an effort to increase the self-efficacy of patients with terminal illness in the Inpatient Room of DKT City Hospital in Kediri

The independent variable in this study is the fulfillment of spiritual needs. The dependent variable in this study is Self Efficacy.

The study was conducted in the Inpatient Room of the Kediri City DKT Hospital on January 20-25, 2017 with 21 respondents. By using the Simple Random Sampling technique. Pearson correlation test was performed with significance level or $\alpha=0.05$ using a computer program. If the value of sig $(\rho)>0.05$, then Ho is accepted, meaning that there is no relationship between the fulfillment of spiritual needs by nurses in an effort to improve the self-efficacy of patients with terminal illness in the Inpatient Room of Kediri City DKT Hospital. If the value of sig ( $\rho$ ) $\leq 0.05$ then Ho is rejected, it means that there is a relationship between spiritual needs fulfillment by nurses in an effort to increase self-efficacy of patients with terminal illness in the Inpatient Room of Kediri City DKT Hospital.

\section{RESULTS}

Meeting spiritual needs

\begin{tabular}{llcc}
\hline No & $\begin{array}{c}\text { Meeting Spiritual } \\
\text { Needs }\end{array}$ & Quantity & Prosentase \\
\hline 1 & Low & 4 & 19 \\
2 & Moderate & 14 & 66,7 \\
3 & High & 3 & 14,3 \\
4 & Very High & 0 & 0 \\
\hline & Total & 21 & $100 \%$ \\
\hline
\end{tabular}

Most of the respondents $66.7 \%$ (14 people) had moderate spiritual needs

Self Efficacy

\begin{tabular}{llcc}
\hline No & self efficacy & Quantity & Prosentase \\
\hline 1 & Not Sure & 0 & 0 \\
2 & Not too Sure & 12 & 57,1 \\
3 & Sometimes & 6 & 28,6 \\
4 & Sure & 3 & 14,3 \\
5 & Very Sure & 0 & 0 \\
\hline & Total & 21 & $100 \%$ \\
\hline
\end{tabular}

Most respondents $57.1 \%$ (12 people) were not too sure they would be able to live the rest of their lives better 
STRADA Jurnal Ilmiah Kesehatan

DOI: $\underline{10.30994 / \text { sjik.v9i1.284 }}$

ISSN: 2252-3847 (print); 2614-350X (online)

Vol.9 No.1. May 2020. Page.272-278

Fulfillment of spiritual needs by nurses with self-efficacy of patients with terminal illness

\begin{tabular}{|l|c|c|}
\hline $\begin{array}{c}\text { Correlation } \\
\text { Analysis }\end{array}$ & $\begin{array}{c}\text { (Correlation } \\
\text { Value) } \\
\mathrm{r}\end{array}$ & Significance \\
\hline $\begin{array}{l}\text { Spiritual needs } \\
\text { with self } \\
\text { efficacy }\end{array}$ & 0,576 & 0,006 \\
\hline
\end{tabular}

From the statistical test results, the $p$-value is $p=0.006$, which means it is smaller than the value of $\alpha=0.05(\mathrm{p}=0.006<\alpha=0.05)$, it means rejecting Ho, the conclusion is that there is a relationship between the fulfillment of spiritual needs by nurses in an effort to increase self efficacy patients with terminal illness in the Inpatient Room of Kediri City DKT Hospital

\section{DISCUSSION}

The results showed that most respondents with terminal illness showed that $66.7 \%$ (14 people) were fulfilling spiritual needs by moderate nurses, 4 respondents (19\%) had low spiritual needs. The goal of nursing a client with a spiritual terminal condition. Increasing spiritual tranquility has a greater meaning than just asking the clergy. When death approaches, patients often seek calm. Nurses and families can help patients express their values and beliefs. dying patients may seek to find purpose and meaning in life before surrendering to death (McSherry, 2010).

The results showed that the majority of respondents $52 \%$ ( 11 people) were over 55 years old. Research shows that young adults become increasingly unafraid of death as they get older. They realize that they might die of chronic illness. They also have a longer past than young adults and give them the opportunity to receive more. People who see their past and believe that they have fulfilled important things and live well have no difficulty in adapting to terminal illness (Kartina, 2010). This means in accordance with the theory that the more age will get closer to God and the fulfillment of their spiritual needs is getting stronger and they are resigned to the condition of their illness and are ready when at any time of death.

The results of recapitulation of data meeting the fulfillment of spiritual needs about whether nurses reminded patients to worship 18 respondents (85.7\%) said rarely, and only 3 respondents (14.3\%) said often. The question about whether during being treated to fulfill the spiritual needs of patients is met, 17 respondents $(81 \%)$ said rarely met. Someone with a terminal illness will experience grief and loss. As a nurse we must be able to understand that. Communication with terminal illness clients is not easy communication. Nurses must have knowledge about the illness they are experiencing as well as knowledge about the process of grieving and loss. In communicating nurses use the concept of therapeutic communication. When communicating with clients with such conditions there may be resistance from the client. In dealing with these conditions, nurses use therapeutic communication. Building trusting and caring relationships with clients and families through the use of therapeutic communication forms the basis for palliative service interventions. Mok and Chiu (2004) are quoted from Potter and Perry (2010). This is consistent with the theory that if nurses implement appropriate 


\section{STRADA Jurnal Ilmiah Kesehatan}

DOI: $10.30994 /$ sjik.v9i1.284

ISSN: 2252-3847 (print); 2614-350X (online)

Vol.9 No.1. May 2020. Page.272-278

communication in guiding terminal patients, the fulfillment of the spiritual needs of patients will be fulfilled because one of the nurses' tasks is to fulfill spiritual needs.

Since April 2016 the DKT Hospital has had an MOU or collaboration with the Ministry of Religion by bringing in Muslim clerics every Tuesday. They come to each treatment and provide spiritual guidance for patients who are treated especially in terminal patients. For patients whose religion is other than Islam the spiritual service is carried out if the family or patient wishes. The rest when entering prayer time through audio the hospital always reminds all residents of the prayer hospital and harden the call to prayer.

The results showed that nearly half of the respondents $57.1 \%$ (12 people) were not too sure they would be able to live the rest of their lives better, and only 3 respondents $(14.3 \%)$ were sure they could live the rest of their lives better. Self-efficacy of patients with terminal illness is a person's beliefs about their ability to produce planned levels of performance, where those abilities are trained, driven by events that affect one's life Bandura (1994) in Mustaqim (2011). Researchers believe that terminal patients' confidence in recovering is very little because on average they have had this terminal disease for a long time. The results showed that almost half of respondents, $48 \%$ (10 people) had been suffering from the disease for more than 5 years and 6 respondents $(28 \%)$ had suffered from terminal illness for 1 to 5 years. Self-efficacy is formed through a learning process that can occur in an organization or company where individuals experience pain. Self efficacy is formed as a process of adaptation and learning that exists in an illness situation. The longer a person is sick, the higher the self-efficacy that an individual has in dealing with his illness, but it does not rule out the possibility that the selfefficacy possessed by that individual actually tends to decrease or remain. It also really depends on how individuals deal with the successes and failures they experience during treatment (Mustaqim, 2011). From the description above the researchers argue that respondents who have long suffered from terminal illnesses already understand very well about the disease and the percentage of recovery, so that the average terminal patient who has long resigned to his recovery and is not sure of his recovery.

The results showed that almost half of the respondents $52 \%$ (11 people) were aged over 55 years, and only 1 respondent aged 20-35 years. Self efficacy is formed through a process of social learning that can last for a lifetime. Older individuals tend to have more time span and experience in overcoming something that happens when compared to younger individuals, who may still have less experience and events in their lives. Older individuals will be better able to overcome obstacles in their lives compared to younger individuals, this is also related to experiences that individuals have throughout their life span (Alwisol, 2012). Researchers argue that the average age of terminal patients is old, so they have a lot of experience in dealing with various kinds of disasters, and know about the condition of the disease. From the results of recapitulation of data questions about the Generality indicator shows that the majority of respondents 13 people (61.9) are less able to realize almost all their life goals while sick and on the strength indicator, shows that the majority of respondents 14 people $(66.7 \%)$ can not do activities that are not too heavy. This generality dimension is related to one's belief in one's ability to be different in terms of generalization. This means that someone might judge their beliefs for certain activities. This strength dimension is related to the level of strength or stability of a person towards his belief. This dimension of strength is related to the level of strength or 


\section{STRADA Jurnal Ilmiah Kesehatan}

DOI: $10.30994 /$ sjik.v9i1.284

stability of a person towards his belief Bandura (1997) in Mustaqim (2011). There is a congruence between the facts and the theory that most of the respondents' self efficacy is low because they are not sure to be able to meet their daily needs and feel lemh in carrying out activities that they could have done.

Statistical test results obtained p-value is $\mathrm{p}=0.006$, which means it is smaller than the value of $\alpha=0.05(\mathrm{p}=0.006<\alpha=0.05)$ means Ho rejects, the conclusion is that there is a relationship between fulfilling spiritual needs by nurses in an effort to increase self efficacy patients with terminal illness in the Inpatient Room of Kediri City DKT Hospital.

Correlation Coefficient value of $r=0.576$ means that the level of closeness of the relationship between meeting the fulfillment of spiritual needs with self-efficacy of patients with terminal disease is rather low, and no negative sign means positive means the level of closeness is parallel with the better the fulfillment of meeting spiritual needs, the better the self efficacy patients with terminal illness. The results of the cross tabulation between meeting spiritual needs with self efficacy of patients with terminal illness can be seen that those who are fulfilling spiritual needs are not too sure of healing or are sure to live a better rest of life, as many as 8 people (38.1\%), this shows that meeting spiritual needs is being able to influence a person to live the rest of his life better at $38.1 \%$

From the description above, the researcher is of the opinion that there is a relationship between the fulfillment of spiritual needs by nurses in an effort to increase the patient's selfefficacy with terminal illness in the Inpatient Room of the Kediri City DKT Hospital. Those who fulfill their spiritual needs are not too sure of their recovery and the level of closeness of the relationship is rather low. It is important for nurses who care for dying patients to be aware of their own feelings about death and about their patients. It's hard to see the person you have treated died. Especially difficult if a child or young person who died. When it is not possible to prevent patients from dying, and medical care is no longer possible or is no longer useful, nurses provide supporting care to patients and families. The main goal of this treatment is to keep the patient comfortable and pain free. make the last days of the patient as good as possible for both the patient and family, with as little suffering as possible, helping patients die peacefully (spiritual calm), providing comfort for the family.

\section{CONCLUSION}

There is a relationship between meeting the spiritual needs of nurses with self-efficacy of patients with terminal illness in the Inpatient Room of the DKT City Hospital in Kediri, with it is expected that the patient's family will always accompany the client for every care that has been determined by health workers and nurses and provide emotional support, support facilities, support information (knowledge), material and spiritual support during the process of undergoing treatment, always accompanying and reminding prayer schedules and bringing prayer books to read or read them.

\section{REFERENCE}

Alwisol. 2012. Psikologi Kepribadian, Malang: UM Press

Brunner and Suddarth. 2010. Text Book Of Medical Surgical Nursing 12th Edition. 


\section{STRADA Jurnal Ilmiah Kesehatan}

DOI: $10.30994 /$ sjik.v9i1.284

ISSN: 2252-3847 (print); 2614-350X (online)

Vol.9 No.1. May 2020. Page.272-278

Bulechek G. M., \& McCloskey, J. C. 2010. Nursing Interventions Classifications (NIC) Edisi 4. St.Louis Missouri: Mosby

Chism,L.A\&Magnan M.A. 2010. The Relationship of Nursing Student' Spiritual Care Perspectives to Their Expressions of spiritual empathi.

Departeman Kesehatan RI. 2011. Epidemiologi Penyakit Tidak Menular, Rineka Cipta,. Jakarta.

Ferrel, B. R., Coyle. N. 2012. Oxford Textbook of Palliative Nursing. $3^{\text {rd }}$ ed. Oxford Univercity Press, Incorporated

Galek et al. 2012. Kecerdasan Emosional. Jakarta: Gramedia Pustaka Utama

Kozier. 2010. Fundamental of Nursing, Seventh Edition, Vol.2, Jakarta: EGC

Maddux. 2012. Self-efficacy. In C. R. Snyder \& Lopez.(Eds.), Handbook of Positive Psychology (pp. 277-287). New York, NY: Oxford University Press.

McSherry Wildfred dan Ross, L. 2010. Spiritual Assessment in Health care Practice. M\&K Update Ltd.

Mustaqim. 2011. Psikologi Pendidikan. Yoyakarta: Pustaka Pelajar.

Nataliza. 2011. Pengaruh Pelayanan Kebutuhan Spiritual Oleh Perawat. Terhadap Tingkat Kecemasan Pasien Pre Operasi di Ruang Rawat RSI. Skripsi Mahasiswa Universitas Sumatra Utara.

Papalia. 2013. Penyakit terminal Illnes, Jakarta. EGC.

Poeter \& Perry. 2012. Buku Ajar Fundamental Keperawatan Konsep, Proses, dan. Praktik. Edisi 4 volume 1.EGC. Jakarta

Spaulding Marguerite G., Dean T. Spaulding, and Katherine H. Voegtle 2012 Methods in Educational Research. San Francisco: Jossey-Bass Imprint

Sumiati,dkk., 2011. Metode Pembelajaran Pendekatan Individual. Bandung: Rancaekek Kencana

Sutrisno. 2012. Manajemen penyakit terminal Edisi pertama. Jakarta: Kencana Prenada Media Group

Yani. 2012. Asuhan Keperawatan pada klien dengan kebutuhan spiritual. Jakarta. EGC 